ПОВЕЗАНОСТ СНИЖЕНЕ КОНЦЕНТРАЦИЈЕ СЕРУМСКОГ 25(ОН)D ВИТАМИНА У НАСТАНКУ ОСТЕОПОРОТИЧНИХ ПРЕЛОМА

Тања Јанковић ${ }^{1}$, Јелена Звекић-Сворцан ${ }^{2}$, Софија Субин-Теодосијевић ${ }^{3}$, Оливера Гојков-Жигић ${ }^{4}$

\title{
RELATIONSHIP BETWEEN THE LEVEL OF SERUM 25(OH)D IN OSTEOPOROTIC FRACTURES
}

Tanja Janković, Jelena Zvekić-Svorcan, Sofija Subin-Teodosijević, Olivera Gojkov-Žigić

\section{Сажетак}

Увод: Недостатак витамина Д повезан је са настанком остеопорозе и остеопоротичних прелома. Снижена вредност серумског 25(ОН)D сматра се вредност испод $30 \mathrm{ng} / \mathrm{ml}(75 \mathrm{nmol} / \mathrm{l})$.

Циљ рада: Сврха рада је утврдити повезаност концентрачије серумског 25(OH)D у настанку остеопоротичних прелома.

Материјал и методе: Анализом је обухваћено 229 болесника оболелих од остеопорозе. Заступьеност жена била је 90,8\% (208/229) и 9,2\% мушкараиа (21/229), просечне старосне доби од 65 година. Болесницима је мерена конщентрачија серумског 25(OH)D ECLIA методом. Код болесника са сниженом вредности серумског 25(OH)D анализирани су резултати остеодензитометрије, одређивана је учесталост прелома на основу анамнестичких података и RTG налаза, користећи „БОНЛИНК“ базу података, која служи за унос и анализу података болесника са остеопорозом.

Резултати: Средња измерена вредност серумског 25(OH)D била је 30,91 ng/ml. Код 86 болесника измерена вредност серумског витамина Д била је изнад $30 \mathrm{~g} / \mathrm{ml}$, док код 142 босленика вредност је била мања од 30 $\mathrm{ng} / \mathrm{ml}$. Заступьеност прелома код болесника са сниженом вредности витамина Д је била

\section{Summary}

Introduction: Vitamin D deficiency is associated with the development of osteoporosis and osteoporotic fractures. Reduced serum 25(OH)D is considered a value below 30ng/ $\mathrm{ml}(75 \mathrm{nmol} / \mathrm{l})$.

Purpose: The purpose of this paper is to determine the correlation between concentration of serum $25(\mathrm{OH}) \mathrm{D}$ in the development of osteoporotic fractures.

Material and methods: The analysis included 229 patients with osteoporosis. It included 90.8\% women (208/229) and 9.2\% men (21/229), median age 65. Concentrations of serum 25(OH)D were measured by ECLIA method. For patients with decreased values of serum 25(OH)D results were analysed by osteodensitometry. The frequency of fractures on the basis of anamnestic data and X-ray was determined using BONLINK database, which is used for data entry and data analysis of patients with osteporosis.

Results: Mean measured total serum 25(OH)D was $30.91 \mathrm{ng} / \mathrm{ml}$. 86 patients had concentration of serum vitamin D above 30ng/ $\mathrm{ml}$, while with 142 the value was less than $30 \mathrm{ng} / \mathrm{ml}$. Presence of fractures in patients with reduced values of vitamin $D$ was $59 \%$ (84/142), while 41\% (58/142) were negative. $37.5 \%(30 / 84)$ had two fractures, $25 \%(21 / 84)$ three, while $10.7 \%$ (9/84) had more than three

\footnotetext{
${ }^{1}$ Прим. др Тања Јанковић, специјалиста физикалне медицине и рехабилитације, субспецијалиста реуматолог, Специјална болница за реуматске болести, Нови Сад.

${ }^{2}$ Мр мед. др Јелена Звекић-Сворцан, специјалиста физикалне медицине и рехабилитације, Специјална болница за реуматске болести, Нови Сад.

${ }^{3}$ Др Софија Субин-Теодосијевић, специјалиста интерне медицине, Општа болница „Др Ђорђе Јовановић“, Зрењанин.

${ }^{4} \mathrm{Mp} \mathrm{мед.} \mathrm{др} \mathrm{Оливера} \mathrm{Гојков-Жигић,} \mathrm{специјалиста} \mathrm{физикалне} \mathrm{медицине} \mathrm{и} \mathrm{рехабилитације,} \mathrm{приватна} \mathrm{Специјалистичка} \mathrm{ординација} \mathrm{за}$ физикалну медицину и рехабилитацију „Medihome“, Бачка Паланка.
} 
59\% (84/142), док 41\% (58/142) их није имало. Два прелома имало је 37,5\% (30/84), 3 прелома 25\% (21/84), а више од три прелома имало је 10,7\% (9/84) болесника. Вертебралне преломе имало је 42,3\% испитаника, док су невертебрални преломи били учесталији и забележени су код 57,7\% болесника. Најчешћа локализација прелома била је у пределу подлактице, што је забележено код 38 болесника (26,8\%).

Закључак: Добијени резултати указују на значај одређивања концентрачије серумског 25(OH)D, као и на тесну повезаност снижених вредности серумског 25(OH)D за настанак остеопоротичних прелома.

Кључне речи: витамин Д, остеопороза, фрактуре. breaks. Vertebral fractures had $42.3 \%$, while nonvertebral fractures were more frequent and were recorded in $57.7 \%$ of patients. The most common location of fracture was in the area of the forearm, recorded in 38 patients (26.8\%).

Conclusion: These results indicate the importance of measuring the concentration of serum $25(\mathrm{OH}) \mathrm{D}$ as well as close connection to lower serum $25(\mathrm{OH}) \mathrm{D}$ in the occurrence of osteoporotic fractures.

Key words: vitamin D, osteoporosis, fractures.

\section{УВОД}

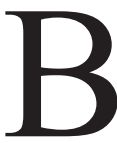

итамин Д има бројне функције у организму. Једна од најзначајних улога огледа се у повећању ресорпције калцијума из танког црева и бубрега, поспешењу минерализације костију, регулацији коштане густине, као и у побољшању неуро-мишићне функције. Концентрација витамина Д се најбоље може измерити одређивањем концентрације 25-хидрокси витамина Д $(25(\mathrm{OH}) \mathrm{D})$ у серуму, чија је минимална вредност која обезбеђује нормално функционисање коштаног система $30 \mathrm{ng} / \mathrm{ml}$ (75 nom/l/ $)^{(1)}$. Међународне студије које су обухватале жене са постменопаузалном остеопорозом $(\mathrm{N}=2.589)$ показале су да велики број ових жена има у серуму мање вредности концентрације 25(OH)D од $30 \mathrm{ng} /$ $\mathrm{ml}$. У Европи ова заступљеност је 57,7\%, Аустралији 60,\%, Азији 71,4\%, Блиском истоку 81,8\%, Латинској Америци 53,4\%(2). Најчешћи фактори који доводе до хиповитаминозе витамина Д су: поремећај исхране, стил живота (излагање сунцу мање од 15 мин. дневно), старост и окултна малапсорција, поремећај функције јетре и бубрега идр.Недостатаквитамина Дповезан је са поремећајем метаболизма калцијума, остеобласном активности, осификацијом матрикса, коштаног ремодулирања и снижењем коштане минералне густине ${ }^{(3)}$. Ово има за последицу настанак остеопорозе и повећања ризика од фрактура ${ }^{(4,5)}$. Више од 1,5 милиона вертебралних и невертебралних фрактура јавља се на бази остеопорозе од које у свету болује више од 200 милиона људи ${ }^{(6)}$. Велике епидемиолошке студије су показале да остеопороза, као најчешћа метаболитичка болест костију, водећи је здраствени и економски проблем у свету, како због масовности, тако и због својих последица које је прате, пре свега прелома, повећаног коморбидитета, морталитета, као и огромних индивидуалних и социјалних трошкова који их прате ${ }^{(7,8)}$.

\section{ЦИЛ РАДА}

Утврдити повезаност нивоа концентрације серумског 25(OH)D у настанку прелома код особа са остеопорозом. 


\section{МАТЕРИЈАЛ И МЕТОДЕ}

Анализом је обухваћено 229 болесника са остеопорозом лечених у Специјалној болници за реуматске болести у Новом Саду. Испитивање је спроведено у периоду од годину дана. Свим болесницима је рађен DEXA преглед. Мерена је минерална коштана густина (BMD) на лумбалној кичми и врату бутне кости, изражена у процентима и стандардним девијацијама (SD), тј. T-скором. Код свих болесника добијена вредност Т-скора, мерена на овим местима, била је једнака или мања од $-2,5 \mathrm{SD}$, што је говорило у прилог постојању остеопорозе, као и мерење концентрације серумског 25(OH)D ECLIA методом. Код болесника са сниженом вредношћу серумског $25(\mathrm{OH})$ D (вредности мање од $30 \mathrm{ng} / \mathrm{ml}$, односно $75 \mathrm{nmol} / 1)$, одређивана је учесталост прелома на основу анамнестичких података и RTG налаза. За анализу података коришћена је „БОНЛИНК“ база података, која служи за унос и анализу података болесника са остеопорозом. У статистичкој анализи коришћене су дескриптивне методе.

\section{РЕЗУЛТАТИ}

Од 229 испитивањем обухваћених болесника, заступљеност жена је била 90,8\% (208/229) и 9,2\% мушкараца (21/229), (графикон 1), средње животне доби 65 година.

Графикон 1. Полна структура болесника са остеопорозом.

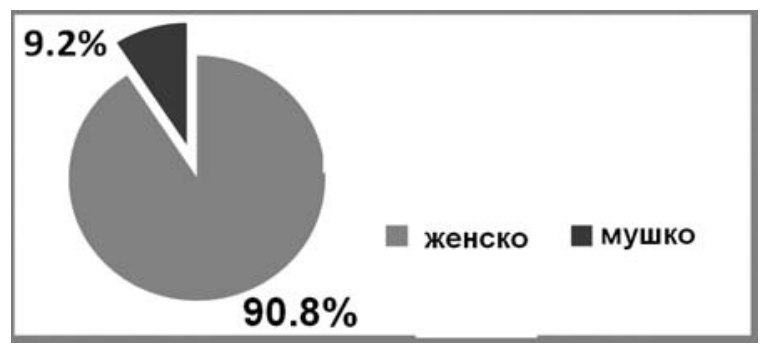

Средња измерена вредност серумског $25(\mathrm{OH}) \mathrm{D}$ била је 30,91 ng/ml. Код 86 болесника измерена вредност серумског витамина D била је изнад $30 \mathrm{~g} / \mathrm{ml}$, док код 142 болесника вредност била је мања од 30 $\mathrm{ng} / \mathrm{ml}$ (графикон 2).
Графикон 2. Број болесника у односу на ниво серумског 25(OH)D.

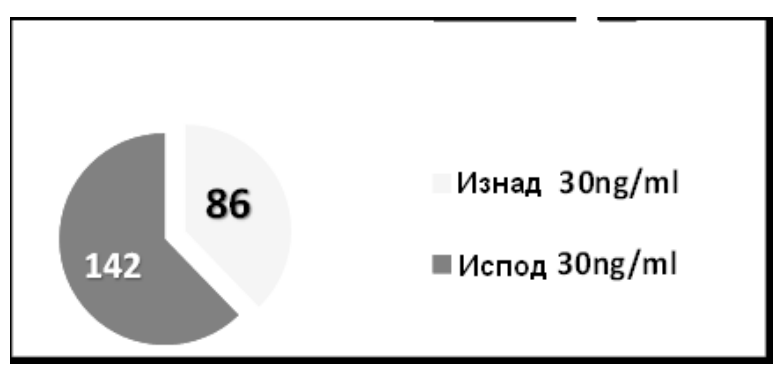

Заступљеност прелома код болесника са сниженом вредности витамина Д је била $59 \%(84 / 142)$, док $41 \%(58 / 142)$ их није имало (графикон 3 ).

Графикон 3. Заступљеност прелома код болесника са сниженом вредности серумског $25(\mathrm{OH}) \mathrm{D}$.

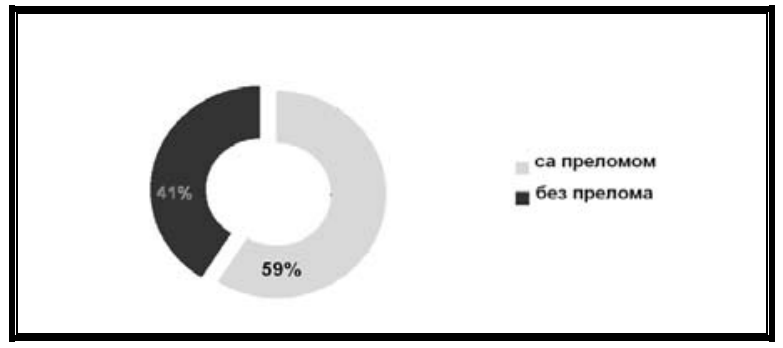

Као што се из табеле 1. види, 2 прелома имало је 37,5\% (30/84), 3 прелома 25\%, $(21 / 84)$, а више од три - 10,7\% (9/84) болесника. Код болесника са 2 и више прелома вредности серумског $25(\mathrm{OH}) \mathrm{D}$ била је мања од $20 \mathrm{ng} / \mathrm{ml}$.

Табела 1. Учесталост прелома код болесника са сниженим вредностима витамина Д.

\begin{tabular}{|c|c|}
\hline Број прелома & Број болесника \\
\hline 2 & $37,5 \%(30 / 84)$ \\
\hline 3 & $25 \%(21 / 84)$ \\
\hline$>3$ & $10,7 \%(9 / 84)$ \\
\hline
\end{tabular}

Што се тиче заступљености вертебралних и невертебралних фрактура (графикон 4), била је у корист невертебралних, чија је учесталост била $57,7 \%$ у односу на верте- 
бралне 42,3\%. Најчешћа локализација фрактура била је у пределу подлактице, што је имало 38 болесника $(26,8 \%)$.

Графикон 4. Заступьеност вертебралних и невертебралних фрактура.

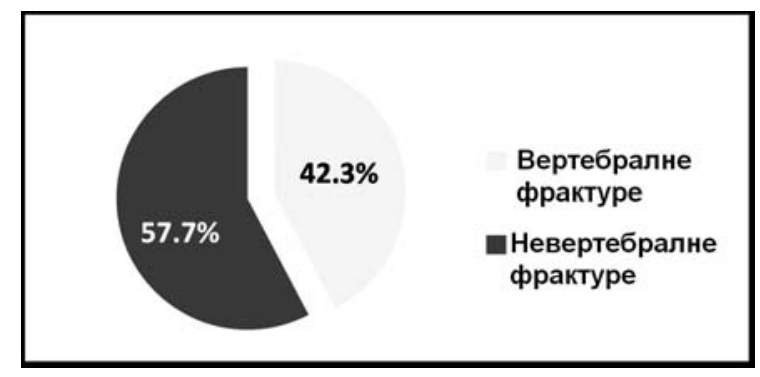

\section{ДИСКУСИЈА}

Остеопороза је поремећај костију, који се одликује малом коштаном масом и микроархитектонским променама које воде повећаном ризику од прелома. Бројни су фактори који на то утичу, а присуство већег броја фактора ризика повећава шансу за њено настајање. С обзиром на значајну улогу витамина Д у метаболизму костију, недовољна концентрација повећава ризик за настанак остеопорозе и остеопоротичних прелома. Од 2005. године недовољно витамина Д (дефицијенција) дефинише се као ниво серумског $25(\mathrm{OH}) \mathrm{D}$ мањи од $30 \mathrm{ng} / \mathrm{ml}$ (75 nmol/l), а тежак недостатак витамина Д (инсуфицијенција) као ниво серумског $25(\mathrm{OH}) \mathrm{D}$ мањи од $10 \mathrm{ng} / \mathrm{ml}(25 \mathrm{nmol} / \mathrm{l})$. За нормалне вредности серумског $25(\mathrm{OH}) \mathrm{D}$ сматра се вредност преко $30 \mathrm{ng} / \mathrm{ml}$ ( $75 \mathrm{nmol} / \mathrm{l})$ (9). Наше истраживање је показало да од 229 испитиваних болесника са остеопорозом, 142 болесника је имало вредност 25(OH) D мању од $30 \mathrm{ng} / \mathrm{ml}$. Тако је у OFELY студији, која је обухватала 669 жена у постменопаузалној остеопорози просечне старости 62,2 године, $73 \%$ болесница имало je снижене вредности 25(OH)D у серуму, тј. био је испод $30 \mathrm{ng} / \mathrm{ml}^{(10)}$. Истраживање спроведено у 18 земаља широм света открило је недовољност витамина. Код 64\% испитаних жена које се лече од остеопорозе, просечна вредност 25(OH)D била је 26,8 $\mathrm{ng} / \mathrm{ml}^{(11)}$. Прелиминарни резултати пилот студија 4 центра у Србији показали су недовољност витамина Д код 95\% жена са постменопаузалном остеопорозом ${ }^{(12,13)}$. Мета анализа 5 RCT, којима је обухваћена учесталост прелома кука у 9.294 испитаника, и у 7 рандомизираних студија са 9.820 испитаника на учесталост других невертебралних прелома показала је да снижена концентрација витамина $25(\mathrm{OH})$ D у серуму игра значјну улогу у њиховом настајању, тј. да је концентрација 25(OH) D у серуму веома важна за антифракторну ефикасност витамина Д. Утврђено је да оптимална концентрација 25(OH)D y серуму за превенцију фрактуре износи 75$100 \mathrm{nmol} / \mathrm{l}^{(14)}$. Резултати добијени нашим истраживањем су показали високи степен повезаности између снижене вредности $25(\mathrm{OH}) \mathrm{D}$ у серуму и појаве прелома на малу трауму. Са снижавањем вредности $25(\mathrm{OH})$ $\mathrm{D}$ учесталост прелома се повећавала, тако да је 2 и више прелома забележено код болесника са вредности 25(OH)D у серуму мањом од $20 \mathrm{ng} / \mathrm{ml}$.

\section{ЗАКЉУЧАК}

Добијени резултати указују на значај одређивања концентрације серумског $25(\mathrm{OH}) \mathrm{D}$, као и на тесну повезаност снижених вредности 25(OH)D у серуму у настанку и учесталости прелома. Стога је неопходно његово редовно праћење и корекција кроз адекватан унос у спречавању будућих прелома. 


\section{ЛИТЕРАТУРА}

1. Chapuy MC, Presiosi P, Maamer, et al. Prevalence of vitamin D insufficiency in an adult normal population. Osteoporos Int 1997; 7: 439-43.

2. A.Mithal-DA, Wahl-J-P. et al. Global vitamin $D$ status and determinants on hypovitaminosis D. Osteoporos Int 2009; 20: 1807-1820.

3. Perez-Lopez FR. Vitamin D and its implications for musculosceletal health in women: An update. Maturitas 2007; 58: 117-137.

4. Звекић-Сворцан Ј, Миков А, Миков И, Субин-Теодосијевић С, Фактори ризика, локализација и учесталост фрактура код пацијената са смањеном коштаном густином. Здравствена заштита 2011; 40(6): 64-68.

5. Јанковић Т, Звекић-Сворцан J, Лазаревић М, Ердељан Б, Стојковић С. Учесталост и локализачија прелома у односу на животно доба болесника резултат „БОНЛИНК“ програма. Acta Rheumatologica Belgradensia 2011; 41(1): 124.

6. Nampei A, Hashimoto J. Bone fracture and the healing mechanisms. Metabolic bone disease and skeletal healing. Clin Calcium 2009; 19(5): 648-52.

7. National Osteoporosis Foundation. America's bone health: The state of osteoporosis and loew bone mass in our nation. Washington, DC: National Osteoporosis Foundation, 2002.
8. Compston JE, Papapoulos SE, Blanchard $\mathrm{F}, \mathrm{On}$ behalf of a Working party from European Union Member States. Reopor on osteoporosis in the European Community, current status and recommendations for the future. Osteoporos Int 1998; 8: 531-4.

9. Dawson-Hughes B, Heaney RP, Holick MF, Lips P, Meunier PJ, Vieth R. Estimates of optimal vitamin D status. Osteoporos Int 2005; 16(7): 713-6.

10. Sornay-Rendu E, Munoz F, Garnero P, Duboeuf F, Delmas PD. Identification of osteopenic women at high risk of facture: the OFELY study. J Bone Miner Res 2005; 20(10): 1813-9.

11. Bruyere O, Malaise O, Neuprez A, Reginster JY, WHO Collaborating Center for Public Health. High prevalence of inadequate serum vitamin D levels in osteoporotic European postmenopausal women. In: Abstract of IOF World Congress on Osteoporosis. 2006.o.S33.P142SA.

12. Анђелковић 3, Значај одређивања статуса витамина Д у постменопаузалној остеопорози. Balneoclimatologia 2009; 33(4): 3-9. 13. Миленковић $\mathrm{C}$, Димић $\mathrm{A}$, Станковић А, Алексић И, Петровић Д, Статус витамина Д код жена са постменопаузалном остеопорозом. Acta Medica Medianae 2010; vol 49(4): 16-18. 14. Bischoff-Ferrari HA, et al. Fracture prevention with vitamin D supplementation: a meta-analysis of randomized controlled trials. JAMA 2005; 293: 2257-64.

Контакт: Прим. др Тања Јанковић, лекар специјалиста физикалне медицине и рехабилитације, субспецијалиста реуматолог, Специјална болница за реуматске болести, Футошка 68, Нови Сад, e-mail: tanjajankovic13@yahoo.com 